\title{
Evaluation of an Indirect Hemagglutination Test for the Diagnosis of Human Leptospirosis
}

\author{
CATHERINE R. SULZER, ${ }^{*}$ JAMES W. GLOSSER, FAYE ROGERS, WALLIS L. JONES, AND MARY \\ FRIX \\ Center for Disease Control, Atlanta, Georgia 30333* and Department of Livestock, State Capitol, \\ Helena, Montana 59601
}

Received for publication 7 April 1975

\begin{abstract}
A presumptive hemagglutination test for the serological diagnosis of leptospirosis in humans is described. The antigen was prepared from a soluble alcohol extract of an andamana strain sorbed to human O-negative erythrocytes and preserved by pyruvic aldehyde fixation. In this study, the overall sensitivity of the hemagglutination test was $92 \%$ in contrast to $69 \%$ for the presumptive slide agglutination test. The specificity was $95 \%$ for the hemagglutination test in comparison with $83 \%$ for the slide test.
\end{abstract}

Diagnosis of leptospirosis in humans and in animals is almost entirely dependent on laboratory findings. The problems encountered in laboratory confirmation of the disease are varied and complex. Leptospires can be isolated from blood and/or urine by use of artificial media and/or animal inoculation (9). However, this procedure has limitations, since as a rule isolation requires several weeks and is usually possible only during the early stages of the disease. The fluorescent antibody technique has been used to demonstrate leptospires in urine and tissues; however, the sensitivity and specificity of the various modifications of this technique have not had sufficient evaluation to establish this method as a routine diagnostic test.

The most frequently used diagnostic approach has been the serological demonstration of antibodies in serum specimens. The microscopic agglutination (MA) test performed with live antigens is the serological test of choice in reference laboratories because of its high degree of specificity and sensitivity $(2,10)$. However, the MA test requires the maintenance of 12 to 15 leptospiral serotypes in the active growth phase on a routine basis, a requirement far beyond the scope and capability of a routine diagnostic laboratory. A macroscopic slide agglutination (ST) test has been developed for use in screening human serum samples (6). This procedure is relatively simple and lends itself to easy application on a routine basis, but the quality and dependability of the antigens used in this procedure have been questioned in recent years. Furthermore, four antigenic pools, each containing three serotypes, are used because of the antigenic disparity of the various leptosipral serotypes.
A genus-specific leptospiral hemolytic test has been described in which passive hemolysis of sheep erythrocytes (RBC) was used $(1,5)$. Recently this technique was modified to one of passive hemagglutination (HA) for quantitating leptospiral antibodies (7-9).

The purposes of this study were (i) to determine the sensitivity and specificity of the HA test in detecting serologically confirmed cases of leptospirosis and (ii) to evaluate the application of the HA test as a screening test by comparing it to the ST antigens.

\section{MATERIALS AND METHODS}

HA test. The HA test was patterned after the previously reported techniques (3-9) with the following modifications. (i) Serotype andamana $\mathrm{CH} 11$ extracts were used as the sensitizing $\mathrm{HA}$ antigen. (ii) Sensitized human O-negative RBC were preserved by pyruvic aldehyde fixation as follows. For every 1.5 volumes of $40 \%$ pyruvic aldehyde aqueous solution ( $\mathrm{pH} 7.0$ ), 0.7 volume of $0.15 \mathrm{M}$ phosphatebuffered saline (pH 8.0) was added. This solution was added to 1 volume of $50 \%$ sensitized RBC suspension (9). The mixture was refrigerated for 4 days at 4 $C$, centrifuged $(4,000 \times g$ for $30 \mathrm{~min})$, washed three times in Kent triethanolamine buffer (4), and resuspended to 10 times the original suspension for storage. Thimerosal was added to a final dilution of $1: 10,000$. The $\mathrm{HA}$ antigen was stored in $5-\mathrm{ml}$ amounts at $4 \mathrm{C}$ and diluted 1:10 when used for both the tuber test and the microtitration system. Nonsensitized RBCs used for controls were preserved in the same manner.

(iii) For the microtitration system, $0.05 \mathrm{ml}$ of serum dilution and $0.025 \mathrm{ml}$ of $\mathrm{HA}$ antigen were used in disposable trays (Linbro IS-MRC-96). Kent buffer was used for all serum dilutions. The sera were screened at a 1:25 dilution; both sensitized and nonsensitized cells were used. Controls included sensitized and nonsensitized cells in Kent buffer and 
known positive and negative sera. After a minimum of $18 \mathrm{~h}$ of incubation at room temperature, the test is read as negative, plus-minus, or positive $(1+$ to $4+)$. A small compact button of $\mathrm{RBC}$ indicates a negative reaction; a small ring similar to a doughnut is read as a plus-minus; and positive reactions vary: an extremely granular reaction is read as $4+$, folded edges of the mat as $3+$, and irregular edges of the mat as $2+$. Any serum demonstrating a positive reaction with unsensitized cells was absorbed with RBC and retested. All sera that were positive at a dilution of $1: 25$ were serially diluted in the microtitration plate to determine the end point dilution.

ST test. The ST test was performed with 12 antigens (obtained from the Biological Products Division, Bureau of Laboratories, Center for Disease Control) according to the standard procedure of Galton et al. (6).

MA test. For this test live cultures of 12 leptospiral serotypes were used as antigens in the microtitration system (2). The serotypes included in the antigen battery were ballum, Mus 127; canicola, Hand Utrecht IV; copenhageni, M20 (Icterohaemorrhagiae); bataviae, Van Tienem; grippotyphosa, Andaman; pyrogenes, Salinem; autumnalis, Akiyama A; pomona, pomona; wolffi, 3705; australis, Ballico; tarassovi, Peregelicin; and georgia, LT 117. The same serotypes were represented in the ST test.

Sera. Human serum specimens from 579 individuals were tested with the HA, MA, and ST tests. The sources of the sera were: (i) reference diagnostic sera from 393 patients which were submitted for leptospiral serology to the Leptospirosis Reference Laboratory, Bacterial Immunology Branch, Center for Disease Control. Paired sera were available from 125 of the patients and single serum specimens from 268. The MA and ST tests were performed simultaneously at the time the sera were submitted. (ii) Seventy-one single serum specimens collected for a brucellosis serosurvey during an investigation of an abbatoir-associated outbreak of brucellosis. Brucella agglutination test results with these sera ranged from negative to a titer of 10,240. Eighteen (25\%) of the 71 persons were diagnosed as having active cases of brucellosis on the basis of clinical and laboratory findings. (iii) Serum specimens collected from 115 clinically normal persons for a shigellosis serosurvey. The shigella antibody titers in this group ranged up to 320 . In categories (ii) and (iii) above, the ST test for leptospirosis was not performed.

All sera were coded, randomized as to order of testing, and stored at $-20 \mathrm{C}$. Two separate laboratories prepared serum dilutions and performed the $\mathrm{HA}$ test. The results obtained in the two laboratories were identical or within one dilution of each other in all cases. Therefore, they were not tabulated separately. All sera having an MA titer of 100 or higher and an HA titer of 25 or higher were treated with 2mercaptoethanol (ME) to determine the amount of ME-resistant (immunoglobulin G) antibody present. One volume of serum was incubated with 1 volume of $0.2 \mathrm{M} \mathrm{ME}$ in $0.85 \% \mathrm{NaCl}$ for $2 \mathrm{~h}$ at $37 \mathrm{C}$ and then diluted serially in saline for the MA test or Kent buffer for the HA test.

\section{RESULTS AND DISCUSSION}

Of the 393 patients screened by the MA test, $155(39 \%)$ had a significant MA titer (100 or higher) to one of the 12 serotypes in the antigen battery. Titers were observed in 229 $(44 \%)$ of the sera tested (Table 1 ). The major presumptive infecting serogroups were Canicola $(38 \%)$, Icterohaemorrhagiae $(23 \%)$, Pomona (18\%), Autumnalis (9\%), and Grippotyphosa (4\%). The MA titers ranged from 100 to 51,200 , with $149(66 \%)$ having a titer of 400 or greater.

Sensitivity and specificity of the HA and ST tests were determined in relation to results of the MA test, which is considered to be the reference procedure $(2,10)$. In this study, the sensitivity of the HA test was superior to that of the ST test for the diagnosis of human leptospiral infection (Table 2). Regardless of the se-

TABLE 1. Distribution of 229 sera positive for leptospiral antibodies by serotype and MA titers ${ }^{a}$

\begin{tabular}{|c|c|c|c|c|c|c|c|}
\hline \multirow{2}{*}{ Serotype } & \multicolumn{7}{|c|}{ MA titers ${ }^{b}$} \\
\hline & 100 & 200 & 400 & 800 & 1,600 & 3,200 & 6,400 \\
\hline $\begin{array}{l}\text { ballum } \\
\text { canicola } \\
\text { icterohaemorrhagiae } \\
\text { bataviae } \\
\text { grippotyphosa } \\
\text { pyrogenes } \\
\text { autumnalis } \\
\text { pomona } \\
\text { wolffi } \\
\text { australis } \\
\text { georgia }\end{array}$ & $\begin{array}{r}2 \\
12 \\
6 \\
1 \\
\\
2 \\
3 \\
8 \\
2\end{array}$ & $\begin{array}{r}12 \\
6 \\
2 \\
6 \\
6 \\
2\end{array}$ & $\begin{array}{r}19 \\
6 \\
1 \\
6 \\
7\end{array}$ & $\begin{array}{l}2 \\
8 \\
5 \\
1 \\
1 \\
3 \\
7 \\
1 \\
1\end{array}$ & $\begin{array}{r}18 \\
13 \\
2 \\
\\
2 \\
6\end{array}$ & $\begin{array}{l}7 \\
8 \\
1 \\
1\end{array}$ & $\begin{array}{r}2 \\
11 \\
10 \\
\\
2 \\
\\
1 \\
6 \\
1\end{array}$ \\
\hline
\end{tabular}

${ }^{a}$ MA test with 11 serotypes in the antigen battery.

${ }^{b}$ Expressed as the reciprocal of the end point titer. 
rum category tested, marked disparities were noted in the relative sensitivity of the two tests. The overall sensitivity of the HA test was $92 \%$, in contrast to $69 \%$ for the ST test (Table 2). The differences in the sensitivity of the two tests were statistically significant for both single serum specimens and paired sera $(P<0.001)$. Analyses of these data were based on the assumption that the HA and ST tests would detect MA-positive sera equally as well. The genus reactivity of the $\mathrm{HA}$ antigen was demonstrated by the fact that this test detected antibodies in 11 serogroups presently recognized in the United States.

The specificity of the HA test was also superior to that noted for the ST test. Of the 324 sera negative by the MA test, the specificity was $97 \%$ for the HA test and only $83 \%$ for the ST test (Table 2). The differences in specificity noted with both single serum specimens and paired sera were statistically significant $(P<0.001)$

The sensitivity of the HA test with the sera from the brucellosis and shigellosis serosurveys was 52 and $77 \%$, respectively. The HA test specificity for these surveys was $99 \%$ for brucellosis and $100 \%$ for shigellosis.

The distribution of the HA and MA titers for the 220 sera from 143 patients is shown in Ta- bles 3 and 4 . Examination of the data suggests that the values obtained by the two tests appear to be directly related. The geometric mean titers of the HA tests were consistently lower than MA at each titer level. Eighty-four percent (185) of the MA test-positive serum had higher titers than HA titers.

Of the 229 sera having MA titers, 42, (18\%) retained antibody activity (immunoglobulin $\mathrm{G}$ ) after treatment (Table 5). Moreover, sera that maintained titers after ME treatment with titers of 3,200 or higher were convalescent sera. All HA-positive sera were nonreactive when treated with $\mathrm{ME}$, which indicates the probable dominant role of immunoglobulin $\mathbf{M}$ antibody in this reaction.

The test in which an alcoholic extract of an andamana strain was used with pyruvic aldehyde fixation had the advantage of a somewhat broader cross-reaction pattern among the serogroups than our previous method (8), in which patoc extract was used with glutaraldehyde fixation. Other advantages of the present test are that the yield of finished antigen from serotype andamana is greater than the yield from patoc per liter and that the andamana antigen is easier to cultivate.

The test still remains to be evaluated in the

TABLE 2. Sensitivity and specificity of the indirect HA test and ST test in the detection of leptospiral antibodies in single sera from 371 patients suspected of having leptospiral infection

\begin{tabular}{l|c|c|c|c}
\hline \multirow{2}{*}{ Serum specimen } & \multicolumn{2}{|c|}{ Sensitivity $^{a}$} & \multicolumn{2}{c}{ Specificity $^{b}$} \\
\cline { 2 - 5 } & IHA & ST & IHA & ST \\
\hline No designation & $87 / 96(91)$ & $64 / 96(67)$ & $170 / 172(99)$ & $141 / 172(82)$ \\
Acute & $37 / 43(86)$ & $34 / 43(79)$ & $75 / 83(90)$ & $70 / 83(84)$ \\
Convalescent & $53 / 56(95)$ & $41 / 56(73)$ & $68 / 69(99)$ & $58 / 69(84)$ \\
Late convalescent & $32 / 34(94)$ & $18 / 34(53)$ & $0 / 0$ & $0 / 0$ \\
\hline
\end{tabular}

${ }^{a}$ IHA, Indirect HA; number of positive sera/total number of MA positive (percent).

${ }^{b}$ Number of negative sera/total number of MA negative (percent).

TABLE 3. Distribution of 114 paired serum specimens from 51 cases of leptospirosis by MA and indirect HA titers

\begin{tabular}{|c|c|c|c|c|c|c|c|c|c|c|c|c|}
\hline \multirow{2}{*}{$\begin{array}{c}\text { MA } \\
\text { titers }\end{array}$} & \multirow{2}{*}{$\begin{array}{l}\text { No. of } \\
\text { sera }\end{array}$} & \multicolumn{10}{|c|}{ HA titers ${ }^{a}$} & \multirow{2}{*}{$\begin{array}{c}\text { Geo- } \\
\text { metric } \\
\text { mean } \\
\text { titer } \\
\text { (HA) }\end{array}$} \\
\hline & & $<25$ & 25 & 50 & 400 & 200 & 400 & 800 & 1,600 & 3,200 & 6,400 & \\
\hline $\begin{array}{r}<100 \\
100 \\
200 \\
400 \\
800 \\
1,600 \\
3,200 \\
\geq 6,400\end{array}$ & $\begin{array}{r}18 \\
14 \\
16 \\
15 \\
13 \\
18 \\
9 \\
11\end{array}$ & $\begin{array}{l}(50)^{b} 9 \\
(21) 3 \\
(38) 6\end{array}$ & $\begin{array}{r}(17) 3 \\
(8) 1 \\
(25) 4 \\
(20) 3\end{array}$ & $\begin{array}{l}(33) 6 \\
(50) 7 \\
(12) 2 \\
(20) 3 \\
(23) 3 \\
(11) 2\end{array}$ & $\begin{array}{l}(25) 4 \\
(27) 4 \\
(23) 3 \\
(28) 5 \\
(56) 5\end{array}$ & $\begin{array}{l}\text { (21) } 3 \\
\\
(33) 5 \\
(23) 3 \\
(33) 6 \\
\text { (36) } 4\end{array}$ & $\begin{array}{l}\text { (17) } 3 \\
(22) 2 \\
(27) 3\end{array}$ & (31) 4 & $\begin{array}{l}\text { (11) } 2 \\
(22) 2 \\
\text { (10) } 1\end{array}$ & & (27) 3 & $\begin{array}{r}22 \\
48 \\
30 \\
83 \\
190 \\
200 \\
252 \\
751\end{array}$ \\
\hline
\end{tabular}

a Titers are expressed as the end point dilution factor

${ }^{\circ}$ Number in parentheses indicates percentage. 
TABLE 4. Distribution of 96 serum samples from 96 patients with leptospirosis by MA and indirect HA titers

\begin{tabular}{|c|c|c|c|c|c|c|c|c|c|c|}
\hline \multirow{2}{*}{$\begin{array}{c}\text { MA } \\
\text { titers }\end{array}$} & \multirow{2}{*}{$\begin{array}{l}\text { No. of } \\
\text { sera }\end{array}$} & \multicolumn{8}{|c|}{ HA titers ${ }^{a}$} & \multirow{2}{*}{$\begin{array}{c}\text { Geo- } \\
\text { metric } \\
\text { mean } \\
\text { titer } \\
\text { (HA) }\end{array}$} \\
\hline & & Negative & 25 & 50 & 100 & 200 & 400 & 800 & 1,600 & \\
\hline $\begin{array}{r}\text { Negative } \\
100 \\
200 \\
400 \\
800 \\
1,600 \\
3,200 \\
" ' 6,400\end{array}$ & $\begin{array}{r}0 \\
20 \\
7 \\
19 \\
12 \\
21 \\
6 \\
11\end{array}$ & $(45)^{b} 9$ & $\begin{array}{l}\text { (15) } 3 \\
(29) 2 \\
(38) 7 \\
(33) 4 \\
(24) 5\end{array}$ & $\begin{array}{l}\text { (10) } 2 \\
(29) 2 \\
(27) 5 \\
(25) 3 \\
(20) 4 \\
(33) 2 \\
(27) 3\end{array}$ & $\begin{array}{l}(10) 2 \\
(42) 3 \\
(10) 2 \\
(25) 3 \\
(14) 3 \\
(33) 2 \\
(27) 3\end{array}$ & $\begin{array}{l}\text { (20) } 4 \\
\\
(15) 3 \\
(17) 2 \\
(14) 3 \\
(33) 2 \\
(18) 2\end{array}$ & $\begin{array}{l}(10) 2 \\
(10) 2 \\
\text { (18) } 2\end{array}$ & (10) 2 & $\begin{array}{l}\text { (10) } 2 \\
\text { (10) } 1\end{array}$ & $\begin{array}{r}34 \\
55 \\
65 \\
59 \\
126 \\
100 \\
155\end{array}$ \\
\hline
\end{tabular}

${ }^{a}$ Titers are expressed as the end point dilution factor.

${ }^{b}$ Number in parentheses indicates percentage.

TABLE 5. Distribution of ME-resistant MA titers in 229 sera positive for leptospiral antibodies ${ }^{a}$

\begin{tabular}{|c|c|c|c|c|c|c|c|}
\hline \multirow{2}{*}{ MA titers ${ }^{b}$} & \multicolumn{6}{|c|}{ No. of sera having ME-resistant MA titers ${ }^{c}$} & \multirow{2}{*}{ Total sera tested } \\
\hline & 50 & 100 & 200 & 400 & 800 & 1,600 & \\
\hline 100 & $-d$ & - & - & - & - & - & 36 \\
\hline 200 & - & - & - & - & - & - & 34 \\
\hline 400 & 2 & 3 & - & 1 & - & - & 39 \\
\hline 800 & 3 & 2 & 1 & 5 & - & - & 29 \\
\hline 1,600 & 1 & - & 一 & 1 & - & - & 41 \\
\hline 3,200 & 1 & 1 & - & - & 6 & - & 17 \\
\hline$\geq 6,400$ & 2 & 3 & - & - & 3 & 7 & 33 \\
\hline
\end{tabular}

${ }^{a}$ Microscopic agglutination test using 12 serotypes in the antigen battery.

${ }^{b}$ Expressed as the end point dilution factor of the highest serum dilution.

' Expressed as the end point dilution factor of the highest serum dilution in serum treated with ME.

${ }^{d}-$, Negative at an initial dilution of 1:50.

field, with extensive culture examination performed on serum from each patient included in the evaluation.

\section{LITERATURE CITED}

1. Baker, L. A., and C. D. Cox. 1973. Quantitative assay for genus-specific leptospiral antigen and antibody. Appl. Microbiol. 25:697-698.

2. Cole, J. R., C. R. Sulzer, and A. R. Pursell. 1973 Improved microtechnique for the leptospiral microscopic agglutination test. Appl. Microbiol. 25:976980.

3. Cox, C. D. 1957. Standardization and stabilization of an extract from Leptospira biflexa and its use in the hemolytic test for leptospirosis. Infect. Dis. 101:203209.

4. Cox, C. D., A. D. Alexander, and L. C. Murphy. 1957. Evaluation of the hemolytic test in the serodiagnosis of human leptospirosis. J. Infect. Dis. 101:210-218.

5. Cox, C. D., R. C. Stover, and R. W. Treicke. 1958. Serologic studies on hemolytic antigen from Leptospira. Proc. Soc. Exp. Biol. Med. 98:265-269.

6. Galton, M. M., D. K. Powers, A. D. Hale, and R. Cornell. 1958. A rapid macroscopic slide screening test for the serodiagnosis of leptospirosis. Am. J. Vet. Res. 99:235-238.

7. Imamura, S., H. Matsui, and Y. Achizawa. 1972. Studies on indirect hemagglutination test for leptospirosis. Jpn. J. Exp. Med. 42:563-568.

8. Sulzer, C. R., and W. L. Jones. 1973. Evaluation of a hemagglutination test for human leptospirosis. Appl. Microbiol. 26:655-657.

9. Sulzer, C. R., and W. L. Jones. 1974. Leptospirosis p. 1-40. In Methods in laboratory diagnosis, DHEW publication no. (CDC) 74-8275.

10. Wolff, J. W. 1954. The laboratory diagnosis of Leptospirosis. Charles C Thomas, Springfield, Ill. 